\title{
Anti-Fas/APO-1 Antibody-mediated Apoptosis of Cultured Human Glioma Cells Induction and Modulation of Sensitivity by Cytokines
}

\author{
Michael Weller, ${ }^{*}$ Karl Frei, ${ }^{\ddagger}$ Peter Groscurth, ${ }^{\mathbf{5}}$ Peter H. Krammer," Yasuhiro Yonekawa, ${ }^{\text {\# }}$ and Adriano Fontana* \\ * Section of Clinical Immunology, Department of Internal Medicine, ${ }^{\ddagger}$ Department of Neurosurgery, and ${ }^{8}$ Department of Anatomy, \\ University of Zürich, School of Medicine, Zürich, Switzerland; and "Division of Immunogenetics, Tumor Immunology Program, \\ German Cancer Research Center, Heidelberg, Germany
}

\section{Abstract}

Fas/APO-1 is a transmembrane protein of the nerve growth factor/TNF $\alpha$ receptor family which signals apoptotic cell death in susceptible target cells. We have investigated the susceptibility of seven human malignant glioma cell lines to Fas/APO-1-dependent apoptosis. Sensitivity to Fas/APO1 antibody-mediated cell killing correlated with cell surface expression of Fas/APO-1. Expression of Fas/APO-1 as well as Fas/APO-1-dependent cytotoxicity were augmented by preexposure of human malignant glioma cells to IFN $\gamma$ and TNF $\alpha$. Further, pretreatment with TGF $\beta_{2}$, IL1 and IL8 enhanced Fas/APO-1 antibody-induced glioma cell apoptosis whereas other cytokines including TNF $\beta$, IL6, macrophage colony-stimulating factor, IL10 and IL13 had no such effect. None of the human malignant glioma cell lines was susceptible to TNF $\alpha$-induced cytotoxicity. Fas/ APO-1 antibody-sensitive glioma cell lines $(n=5)$, but not Fas/APO-1 antibody-resistant glioma cell lines $(n=2)$, became sensitive to TNF $\alpha$ when co-treated with inhibitors of RNA and protein synthesis. Resistance of human glioma cells to Fas/APO-1 antibody-mediated apoptosis was mainly related to low level expression of Fas/APO-1 and appeared not to be linked to overexpression of the antiapoptotic protooncogene, $b c l-2$. Given the resistance of human malignant glioma to surgery, irradiation, chemotherapy and immunotherapy, we propose that Fas/APO-1 may be a promising target for a novel locoregionary approach to human malignant glioma. This strategy gains support from the demonstration of Fas/APO-1 expression in ex vivo human malignant glioma specimens and from the absence of Fas/APO1 in normal human brain parenchyma. (J. Clin. Invest. 1994. 94:954-964.) Key words: apoptosis • Fas/APO-1 • TNFa • glioma $\cdot$ immunotherapy

\section{Introduction}

The prognosis for malignant glioma patients has not been significantly improved for many years. The infiltrative growth pattern of these neoplasms precludes curative neurosurgery and glioma cells fail to respond to irradiation, chemotherapy or

Address correspondence to Adriano Fontana, M.D., Section of Clinical Immunology, Department of Internal Medicine, University of Zürich, School of Medicine, Moussonstrasse 13, CH-8044 Zürich, Switzerland. Received for publication 28 March 1994 and in revised form 1 June 1994.

J. Clin. Invest.

(C) The American Society for Clinical Investigation, Inc. 0021-9738/94/09/0954/11 \$2.00

Volume 94, September 1994, 954-964 immunotherapy (1). It has increasingly been recognized in recent years that malignancy may not exclusively result from enhanced cell proliferation but also from decreased physiological cell death, apoptosis. This was most conclusively demonstrated by the identification of the proto-oncogene, $b c l-2$, which upon deregulated expression in follicular lymphoma confers oncogenicity by rendering cells resistant to the endogenous death program of apoptosis (2). Apoptosis is a physiological form of cell death often referred to as "programmed" since apoptosis is a pathway of developmental cell elimination, e.g., in the immune and nervous system which allows for the safe disposal of cellular remnants without causing harm to surrounding tissue (3-6). This is accomplished by fragmentation of nucleus and cytoplasm into membrane-coated apoptotic bodies which are rapidly cleared from an organism by neighboring cells acting as nonprofessional phagocytes. Exposure to many chemotherapeutic drugs as well as irradiation activate the apoptotic death program in susceptible target cells $(7,8)$. Overexpression of $b c l-2$ has been shown to inhibit not only apoptosis induced by growth factor deprivation but also apoptosis induced therapeutically by chemotherapy and irradiation (9). Novel therapeutic approaches must thus target tumor cells which have developed effective means to escape negative growth regulators and apoptosis-inducing signals.

The identification of Fas/APO-1 (CD 95) $(10,11)$, a transmembrane receptor protein belonging to the nerve growth factor/TNF $\alpha$ receptor family $(12-15)$, led to the detection of a unique endogenous apoptotic death program which may play a significant role in the development of the immune system (16, 17 ), in cytotoxic T cell-mediated killing (18) and in malignant transformation (19). Ligation of Fas/APO-1 has been proven effective in experimental immunotherapy studies of human B lymphoblastoid tumors in nude and SCID mice $(11,20)$. The endogenous Fas/APO-1 ligand has recently been identified as a novel member of the TNF family expressed at the cell surface and shed into the cell culture supernatant $(21,22)$.

We have previously examined nontransformed astrocytes and malignant glioma cells in regard to the synthesis and release of immunosuppressive and proinflammatory cytokines and their possible role as antigen-presenting cells in the central nervous system (23-27). Here we characterize human malignant glioma cell lines in regard to Fas/APO-1 expression, Fas/APO1 -mediated killing and its modulation by cytokines. Our findings warrant the further evaluation of intracerebral Fas/APO-1 targeting as a new immunotherapeutic strategy for the management of human malignant glioma.

\section{Methods}

Materials. Actinomycin D (ActD), ${ }^{1}$ cycloheximide (CHX), mouse, goat, and rabbit IgG, aprotinin, PMSF, leupeptin, sodium fluoride, so-

1. Abbreviations used in this paper: ab, antibody; ActD, actinomycin D; CHX, cycloheximide; M-CSF, macrophage colony-stimulating factor. 
dium vanadate, Hoechst 33258 , acridine orange, poly-L-lysine, diaminobenzidene and PMA were obtained from Sigma Chemical Co. (St. Louis, MO). Human recombinant IL2, IL4, TNF $\alpha$, IFN $\gamma$, biotinylated deoxyuridine triphosphate, RNAse A, proteinase $\mathrm{K}$, avidin-alkaline phosphatase, FITC-streptavidin, nitroblue tetrazolium chloride and 5-bromo-4chloro-3-indolyl phosphate were purchased from Boehringer Mannheim (Rotkreuz, Switzerland). Human recombinant IL1 $\beta$, IL6 and macrophage colony-stimulating factor (M-CSF) were from Genzyme Corp. (Cambridge, MA), IL10 and IL13 from Pepro Tech Inc. (Rocky Hill, $\mathrm{NJ}$ ). Biotinylated anti-mouse IgG and IgM, control mouse IgM, peroxidase and alkaline phosphatase-conjugated anti-mouse IgG and anti-glial fibrillary acidic protein ab were from Dakopatts (Glostrup, Denmark). Lipopolysaccharide (LPS E. coli 0127:B8) and skim milk were purchased from Difco Laboratories (Detroit, MI). Human recombinant TGF $\beta_{2}$ was kindly provided by Sandoz (Basel, Switzerland). IL8 was a gift from Dr. A. Walz (Berne, Switzerland). Mouse anti-human Fas monoclonal ab CH-11, UB2 and FITC-conjugated UB2 were obtained from Kamiya Biomed Co. (Thousand Oaks, CA). Mouse anti-human bcl-2 monoclonal ab was generously provided by Dr. D. Mason (Oxford, UK). FITC-conjugated anti-human CD8 was obtained from Becton Dickinson (Basel, Switzerland).

Cell culture. Human glioma cell lines T98G, obtained from the American Type Culture Collection (Rockville, MD) and LN-18, LN$215, \mathrm{LN}-229, \mathrm{LN}-308, \mathrm{LN}-319$ and LN-405, kindly provided by Dr. N. de Tribolet (Lausanne, Switzerland) were maintained in DME (HyClone, Cramlington, UK) containing 10\% FCS, $2 \mathrm{mM} \mathrm{N}$-acetyl-Lalanyl-L-glutamine (Seromed, Berlin, Germany) and $10 \mu \mathrm{g} / \mathrm{ml}$ gentamycin (GIBCO, Paisley, Scotland) as described (25-27). In most experiments the cells were preactivated by cytokines at subconfluency in DME containing 10\% FCS for $24 \mathrm{~h}$ and then switched to DME/0.5\% FCS for Fas ab or TNF $\alpha$ exposure or modulations thereof for 2-48 h. TNF $\alpha$ release by glioma cells was examined by bioassay using L-M murine fibroblasts (28). The glioma cell lines were mycoplasma-free as assessed by ELISA (Boehringer Mannheim).

Detection of Fas/APO-1 expression. For flow cytometric analysis of Fas/APO-1 expression, glioma cells were scraped off the culture dishes and washed in HBSS. $10^{6}$ cells were resuspended in a volume of $150 \mu \mathrm{l}$ flow cytometry buffer containing PBS, pH 7.4, 1\% FCS, and $0.01 \%$ sodium azide. The samples were incubated with FITC-conjugated Fas monoclonal ab UB2 $(1 \mu \mathrm{g} / \mathrm{ml})$ at $4^{\circ} \mathrm{C}$ for $1 \mathrm{~h}$ and washed twice in flow cytometry buffer. A total of 10,000 viable cells were analysed on an Epics profile analyzer. The percentage of positive cells was calculated directly from the gated histograms.

Soluble protein for Western blotting was harvested from cells lysed for $15 \mathrm{~min}$ on ice in $50 \mathrm{mM}$ Tris- $\mathrm{HCl}, \mathrm{pH} 8$, containing $120 \mathrm{mM} \mathrm{NaCl}$, $0.5 \% \mathrm{NP}-40,2 \mu \mathrm{g} / \mathrm{ml}$ aprotinin, $100 \mu \mathrm{g} / \mathrm{ml}$ PMSF, $10 \mu \mathrm{g} / \mathrm{ml}$ leupeptin, $50 \mathrm{mM}$ sodium fluoride, and $200 \mu \mathrm{M}$ sodium vanadate followed by high-speed centrifugation at $4^{\circ} \mathrm{C} .20 \mu \mathrm{g}$ protein per lane were separated by $12.5 \%$ SDS PAGE and electroblotted to nitrocellulose. Immunodetection involved blocking for $1 \mathrm{~h}$ in $10 \mathrm{mM}$ Tris- $\mathrm{HCl}, \mathrm{pH} \mathrm{7.5,} \mathrm{containing}$ $150 \mathrm{mM} \mathrm{NaCl}, 0.1 \%$ Tween $20,5 \%$ skim milk and $2 \% \mathrm{BSA}$, incubation with Fas ab CH-11 $(5 \mu \mathrm{g} / \mathrm{ml})$ overnight at $4^{\circ} \mathrm{C}$, incubation with biotinylated anti-mouse IgM (1:10,000 in PBS/0.1\% Tween 20), streptavidinalkaline phosphatase $(1: 1,000)$ and nitroblue tetrazolium chloride $(0.41$ $\mathrm{mM}$ ) and 5-bromo-4-chloro-3-indolyl phosphate $(0.38 \mathrm{mM})$ in $200 \mathrm{mM}$ Tris- $\mathrm{HCl}, \mathrm{pH} 9.5$, containing $10 \mathrm{mM} \mathrm{MgCl}{ }_{2}$ as substrate. $\mathrm{Bcl}-2$ expression was detected according to the same protocol except that the first ab was anti-human bcl-2 and the second ab was biotinylated antimouse IgG.

Assessment of Fas ab-mediated cytotoxicity and apoptosis. Cell proliferation and viability were determined by crystal violet staining and trypan blue dye exclusion. Morphological changes induced by Fas ab were closely monitored by phase contrast microscopy and toxicity rated independently by two of us (M. Weller and $\mathrm{K}$. Frei) as no toxicity $(-)$, mild toxicity $(+)$, severe toxicity $(++)$, or complete dissolution of the monolayer $(+++)$. This rating scale was specifically required to assess the effects of cytokines on Fas ab-mediated toxicity which induced both glioma cell proliferation and sensitization to Fas/APO-1-mediated glioma cell apoptosis. Apoptotic cell death was monitored using phase contrast microscopy and acridine orange nuclear staining. DNA fragmentation was examined by quantitative Hoechst 33258 fluorometry, by in situ DNA end labeling and by DNA agarose gel electrophoresis as previously outlined (29). In situ DNA end labeling (30) was performed using terminal transferase $(0.25 \mathrm{U} / \mathrm{ml})$-mediated incorporation of biotinylated deoxyuridine triphosphate $(50 \mu \mathrm{M})$ and streptavidinalkaline phosphatase detection as described above for Western blotting. For in situ DNA end labeling and acridine orange nuclear staining, $10^{4}$ glioma cells were grown for $72 \mathrm{~h}$ on poly-L-lysine $(0.01 \%)$-coated eight-well Labtek chamber glass slides (Nunc, Roskilde, Denmark), treated as indicated and fixed for $5 \mathrm{~min}$ in $4 \%$ formaldehyde in PBS. Glioma cells which detached from the monolayer were harvested from the medium by low speed centrifugation, resuspended in $4 \%$ formaldehyde/PBS and fixed on poly-L-lysine-coated glass slides for staining. Acridine orange $(1 \mu \mathrm{g} / \mathrm{ml})$ in PBS containing $100 \mu \mathrm{g} / \mathrm{ml} \mathrm{RNAse} \mathrm{A}$ was applied to the specimens for $20 \mathrm{~min}$ at room temperature, followed by two washes in PBS and air-drying.

For quantitative DNA fluorometry, $10^{6}$ cells per $\mathrm{ml}$ were lysed in $10 \mathrm{mM}$ Tris- $\mathrm{HCl}, \mathrm{pH} 7.5,10 \mathrm{mM}$ EDTA and $0.2 \%$ Triton X-100 for $10 \mathrm{~min}$ on ice. Fragmented DNA was separated from nucleus-attached DNA by high-speed centrifugation. After disruption of the pellets by brief sonication and RNAse A digestion, fragmented and pelleted DNA were measured by Hoechst $33258(1 \mu \mathrm{g} / \mathrm{ml})$ fluorometry using $360 \mathrm{~nm}$ excitation and $460 \mathrm{~nm}$ emission wave lengths (CytoFluor 2350; Millipore Corp., Bedford, MA). The linear range was between 0.05 and 3 $\mu \mathrm{g} / \mathrm{ml}$ DNA. This assay was performed differentially on cells which had detached from the monolayer and on intact monolayer cells. Percentage fragmentation was calculated by dividing fragmented DNA by the total sum of fragmented and pelleted DNA.

For the demonstration of nucleosomal size DNA fragmentation, glioma cells were lysed as described above for quantitative fluorometry. Nonpelleted DNA was harvested from the supernatants of the cell lysates by phenol dichloromethane extraction and sodium acetate/ethanol precipitation. DNA agarose gel electrophoresis was performed on $1.5 \%$ gels in $10 \mathrm{mM}$ Tris- $\mathrm{HCl}, \mathrm{pH} 8$, containing $1 \mathrm{mM}$ EDTA and $1 \mu \mathrm{g} / \mathrm{ml}$ ethidium bromide.

For transmission electron microscopy glioma cells treated as indicated were fixed for $30 \mathrm{~min}$ at $4^{\circ} \mathrm{C}$ in $0.05 \mathrm{M}$ cacodylate buffer containing $2 \%$ glutaraldehyde and $0.8 \%$ paraformaldehyde, postfixed in 0.1 $\mathrm{M}$ cacodylate buffer containing $1 \% \mathrm{OsO} 4$ and $1.5 \% \mathrm{~K}_{4}(\mathrm{FeCN})_{6}$ and embedded into epon. Adherent monolayer cells were scraped off the dish for fixation, detached cells were collected from the supernatants by low speed centrifugation. Ultrathin sections contrasted with uranyl acetate and lead citrate were examined with a Philips TEM 420 transmission electron microscope.

Immunocytochemical detection of Fas/APO-1 expression in human ex vivo glioma tissue. Cryopreserved human glioma sections were fixed in acetone for $5 \mathrm{~min}$ at $-20^{\circ} \mathrm{C}$, air-dried and blocked for $20 \mathrm{~min}$ with PBS containing $10 \%$ goat serum. The specimens were exposed to mouse anti-human APO-1 ab (11) or anti-human Fas ab UB2 (1 $\mu \mathrm{g} / \mathrm{ml})$ diluted in PBS containing 2\% goat serum and $10 \%$ human serum for $2 \mathrm{~h}$, washed extensively in PBS and subsequently incubated with peroxidaseconjugated anti-mouse IgG diluted 1:100 in PBS containing 2\% goat serum and $10 \%$ human serum. Diaminobenzidene was used as a substrate and Mayer's hematoxylin as counterstain. To confirm specificity of Fas/APO-1 detection, parallel sections were treated with non-immune mouse IgG instead of APO-1 or UB2 ab. To confirm a glial origin of Fas/APO-1-positive cells, parallel sections were reacted with rabbit anti-glial fibrillary acidic protein ab and alkaline phosphatase-labeled anti-mouse IgG using nitroblue tetrazolium chloride and 5-bromo-4chloro-3-indolyl phosphate as substrate as described above.

Statistical analysis. $\mathrm{EC}_{50}$ values were determined by linear regression analysis. Effects of simple treatments were compared by student's $t$ test. Composite treatments were compared by ANOVA.

\section{Results}

Expression of Fas/APO-1 in human malignant glioma cells and its modulation by IFN $\gamma$ and TNF $\alpha$. We initiated our study 


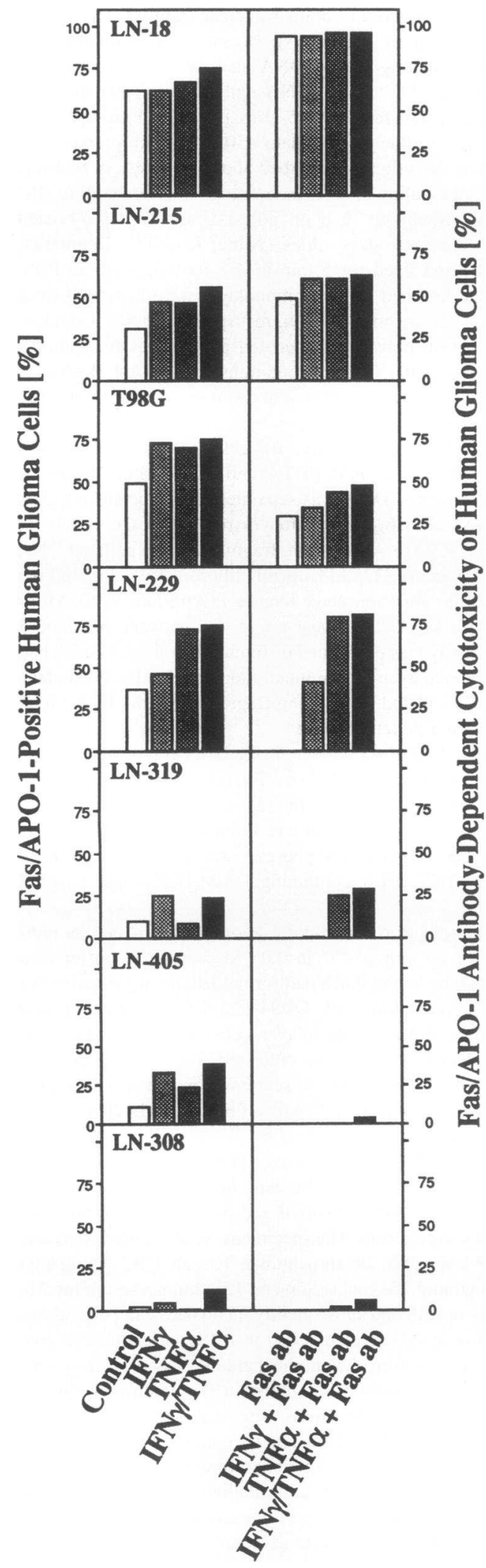

Figure 1. Fas/APO-1 expression and Fas ab-mediated cytotoxicity of human malignant glioma cells. The left panels show constitutive and IFN $\gamma$ - and TNF $\alpha$-induced Fas/APO-1 expression in seven human glioma cell lines assessed by flow cytometry. Human glioma cells were exposed to IFN $\gamma(100 \mathrm{U} / \mathrm{ml})$ or TNF $\alpha(10 \mathrm{ng} / \mathrm{ml})$ or both for $24 \mathrm{~h}$ before flow cytometry. Data are expressed as percent Fas/APO-1positive cells. The right panels illustrate Fas ab-mediated cytotoxicity by examining the constitutive and cytokine-induced expression of Fas/APO-1 in human glioma cells. Since our first flow cytometric experiments showed Fas/APO-1 to be partly sensitive to trypsinization, the adherent glioma cells were subsequently removed by mechanical cell scraping and stained with FITClabeled Fas ab. Flow cytometry revealed that all glioma cell lines examined expressed Fas/APO-1 although the percentage of constitutively Fas/APO-1-positive cells varied between $2 \%$ in $\mathrm{LN}-308$ and $62 \%$ in $\mathrm{LN}-18$ glioma cells (Fig. 1). IFN $\gamma$ and TNF $\alpha$ enhanced the percentage of Fas/APO-1-positive cells. A typical example is given in Fig. 2 which shows the induction of Fas/APO-1 expression in the cytokine-responsive LN-229 cells but only a marginal effect in $\mathrm{LN}-308$ cells. IFN $\gamma$ and TNF $\alpha$ increased not only the percentage of Fas/APO-1-positive cells (Fig. 1) but also the mean fluorescence (data not shown) in all glioma cell lines except LN-308. When the data from the independent experiments were pooled and constitutive expression of Fas/APO-1 by the glioma cells compared with Fas/ APO-1 expression following exposure to IFN $\gamma, \mathrm{TNF} \alpha$, or both cytokines, the combination of both cytokines failed to enhance Fas/APO-1 expression significantly over expression induced by the more potent cytokine alone in any individual cell line (ANOVA). Expression of Fas/APO-1 was confirmed by Western blotting using the monoclonal IgM Fas ab (10) which recognized a protein of $43 \mathrm{kD}$ in all seven glioma cell lines (data not shown).

Human malignant glioma cells are susceptible to cytokinemodulated Fas/APO-1-mediated cytotoxicity. Cytotoxicity assays performed on seven human malignant glioma cell lines cultured for $24 \mathrm{~h}$ with or without Fas monoclonal ab CH-11 (1 $\mu \mathrm{g} / \mathrm{ml})(10)$ showed that there were one highly sensitive line (LN-18), two moderately sensitive lines (LN-215, T98G), and four largely resistant lines (LN-229, LN-319, LN-405, LN-308) (Fig. 1). Preexposure of the glioma cells to IFN $\gamma$ or TNF $\alpha$ or both augmented Fas ab-mediated killing of two sensitive cell lines (LN-215, T98G) and sensitized 2 of 4 resistant cell lines (LN-229, LN-319) to become effective target cells. The $\mathrm{EC}_{50}$ for Fas ab-mediated killing was below $100 \mathrm{ng} / \mathrm{ml}$ in the most sensitive cell line, LN-18. In the resistant glioma cell lines, $\mathrm{LN}$ 308 and LN-405, concentrations of Fas ab up to $10 \mu \mathrm{g} / \mathrm{ml}$ had no adverse effect on viability. Combined exposure to IFN $\gamma$ and TNF $\alpha$ resulted in augmented Fas/APO-1 expression in all

of the same cell lines and its modulation by IFN $\gamma$ and TNF $\alpha$. For cytotoxicity studies subconfluent cell cultures in 96-well plates were left untreated or preexposed to IFN $\gamma(100 \mathrm{U} / \mathrm{ml}), \mathrm{TNF} \alpha(10 \mathrm{ng} / \mathrm{ml})$ or both in DME/10\% FCS for $24 \mathrm{~h}$, exposed to Fas ab $(1 \mu \mathrm{g} / \mathrm{ml})$ in DME/0.5\% FCS for further $24 \mathrm{~h}$, and stained with crystal violet. OD were read in an ELISA reader. Data are expressed as percentage cytotoxicity and are calculated from the relative loss of OD units compared with untreated controls. When compared to cytotoxicity induced by Fas ab alone, cytotoxicity was significantly augmented by preexposure to IFN $\gamma$ in $\mathrm{LN}-215$ and $\mathrm{LN}-229$ and by preexposure to TNF $\alpha$ in $\mathrm{LN}-215$, T98G, LN-229 and LN-319 ( $n=3,{ }^{*} P<0.03$ by ANOVA). Note that cytotoxicity occasionally exceeds the percentage of Fas/APO-1positive cells as determined by flow cytometry, e.g., in LN-18, suggesting that even low levels of Fas/APO-1 expression are sufficient to mediate Fas ab-dependent killing in those cells. Note also that the absence of bars in the three lower right panels indicates $0 \%$ cytotoxicity. IFN $\gamma, \mathrm{TNF} \alpha$, or combinations thereof did not induce toxicity when added alone, and TNF $\alpha$ was mitogenic for most cell lines within the time frame of $24 \mathrm{~h}$ (Table I, data not shown). 


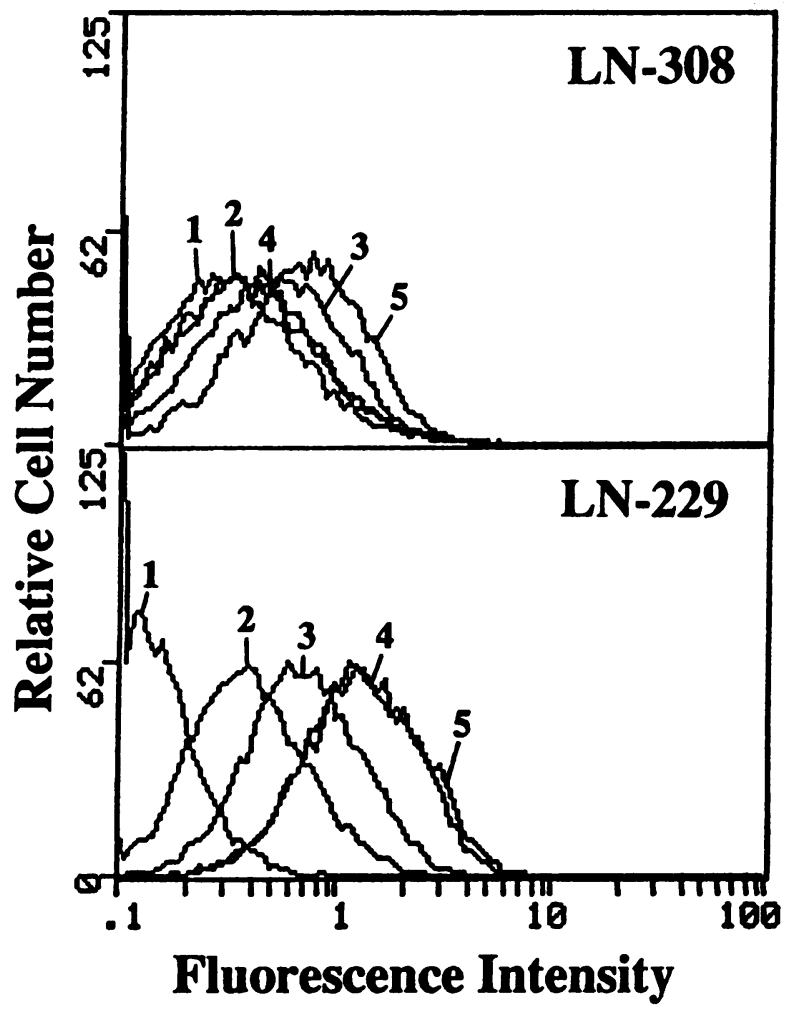

Figure 2. Flow cytometric assessment of constitutive and cytokineinduced Fas/APO-1 expression in LN-308 and LN-229 human malignant glioma cells. The glioma cells were either untreated (2) or stimulated with $100 \mathrm{U} / \mathrm{ml} \mathrm{IFN} \gamma(3), 10 \mathrm{ng} / \mathrm{ml} \mathrm{TNF} \alpha$ (4) or both (5) for 24 $h$. The cells were stained and analyzed as described in Methods using FITC-conjugated anti-human Fas monoclonal ab UB2 (2-5) or antiCD8 as control (1).

glioma cell lines (Fig. 1). Clearly the four glioma cell lines most sensitive to Fas/APO-1 ab (LN-18, LN-215, T98G, LN229) exhibited much higher Fas/APO-1 expression than the less sensitive or resistant cell lines (LN-319, LN-405, LN-308). Overall there was good correlation between cytokine-modulated Fas/APO-1 expression and cytokine-modulated Fas ab-mediated cytotoxicity, e.g., in $\mathrm{LN}-215$ and $\mathrm{LN}-229$ cells. However, IFN $\gamma$ enhanced Fas/APO-1 expression without sensitization to killing in T98G and LN-319, TNF $\alpha$ augmented cytotoxicity but not expression in $\mathrm{LN}-319$, and both cytokines enhanced expression but failed to sensitize in $\mathrm{LN}-405$ cells. Exposure of LN-229 and LN-405 cells to Fas ab in the absence of sensitizing cytokines resulted in enhanced OD values on crystal violet staining which corresponded to enhanced cell proliferation as confirmed by cell counting (data not shown).

Characterization of Fas ab-mediated cytotoxicity of human glioma cells as apoptosis. Exposure of susceptible glioma cells to Fas ab resulted in rounding and detachment of the cells from the monolayer which became first detectable within 4-6 $\mathrm{h}$ and increased until $24 \mathrm{~h}$ after exposure. Fas/APO-1 ab-mediated cytotoxicity was apoptotic rather than necrotic by phase contrast microscopy, acridine orange nuclear staining, in situ DNA end labeling (Fig. 3, $a$ and $b$ ), transmission electron microscopy (Fig. 3, $c-f$ ), quantitative DNA fragmentation analysis (Fig. $4 a$ ) and DNA agarose gel electrophoresis (Fig. $4 b$ ). After exposure of sensitive cell lines to Fas ab, in situ DNA end labeling allowed the detection of DNA breaks in virtually all glioma cells recovered from the medium and in a minor proportion of adherent cells ( $<10 \%$ ) (Fig. 3, $a$ and $b$ ). These observations were corroborated by quantitative DNA fragmentation data obtained using Hoechst 33258 fluorometry (Fig. $4 a$ ). This technique enabled us to confirm that DNA breaks were induced by Fas ab exposure early in the course of apoptosis and preceded cell detachment from the monolayer because a significant increase of DNA fragmentation following Fas ab exposure was detected in DNA extracted not only from detached cells but also from adherent monolayer cells. Note that the relative degree of DNA fragmentation in a cell population uniformly undergoing apoptosis depends on the cell type studied and may not exceed 20-30\% because the majority of genomic DNA remains associated with the apoptotic nuclei and is pelleted upon centrifugation $(31,32)$. While DNA fragmentation data are only shown for LN-229, similar correlation between cytotoxicity, in situ DNA end labeling and quantitative DNA fragmentation data was found in LN-18, LN-215, and T98G. DNA agarose gel electrophoresis revealed the classical DNA pattern of apoptotic cell death, a ladder-like pattern resulting from nucleosomal size DNA fragmentation, in susceptible glioma cells exposed to Fas ab (Fig. $4 \mathrm{~b}$ ). Transmission electron microscopy of Fas ab-sensitive glioma cells exhibited typical ultrastructural features of apoptosis (Fig. 3, $c$ and $d$ ). Early apoptotic stages were characterized by condensation of heterochromatin in the absence of damage to cell organelles (Fig. $3 d$ ). More advanced stages of apoptosis showed disruption of the nuclear envelope and swelling of cell organelles notably endoplasmatic reticulum (Fig. $3 e$ ). Apoptosis was completed by expulsion of heterochromatin, by fragmentation of heterochromatin and cytoplasm into apoptotic bodies and by complete dissolution of the cytoplasm (Fig. $3 f$ ).

Correlation between Fas ab sensitivity and sensitivity to TNF $\alpha$ in the presence of RNA and protein synthesis inhibitors. Sensitivity to Fas ab has been linked to TNF $\alpha$ cytotoxicity (10) and there are homologies between the receptors, Fas/APO-1 and the TNF $\alpha$ receptor $(14,15)$ and between the respective ligands, the Fas/APO-1 ligand and TNF $\alpha$ (21). The initial characterization of Fas ab-mediated cytotoxicity of human glioma cells (Fig. 1) had shown that TNF $\alpha$ pretreatment sensitized some glioma cell lines to Fas ab-mediated killing but had no adverse effects when administered alone. Since sensitivity to TNF $\alpha$ is induced in many cells including glioma cells when RNA or protein synthesis are inhibited (33-35), we compared the effects of ActD and CHX on cell death mediated by Fas ab or TNF $\alpha$ (Table I). Although inhibitors of protein and RNA synthesis block apoptosis in many experimental systems, apoptosis induced by Fas ab in human glioma cells was accelerated by these agents. However, ActD and CHX only enhanced Fas ab-mediated apoptosis in those cell lines which were either constitutively Fas ab sensitive or TNF $\alpha$ inducible. Resistant cell lines were not sensitized to Fas ab by the metabolic inhibitors except a minor effect in LN-319. This was expected since these cells had only low levels of Fas/APO-1 expression. The minor loss in cell density induced by coexposure to Fas ab and ActD or CHX, which did not reach statistical significance (ANOVA, $P=0.01$ ), may be explained by Fas ab-mediated killing of the minority of Fas/APO-1-expressing LN-319 and LN-405 cells.

ActD and $\mathrm{CHX}$ converted the growth-stimulatory activity of TNF $\alpha$ into a strong death signal in Fas ab-sensitive glioma cells but hardly significantly so in resistant cells (Table I). TNF $\alpha$-mediated glioma cell death in the presence of ActD or CHX was apoptotic as assessed by phase contrast and transmis- 

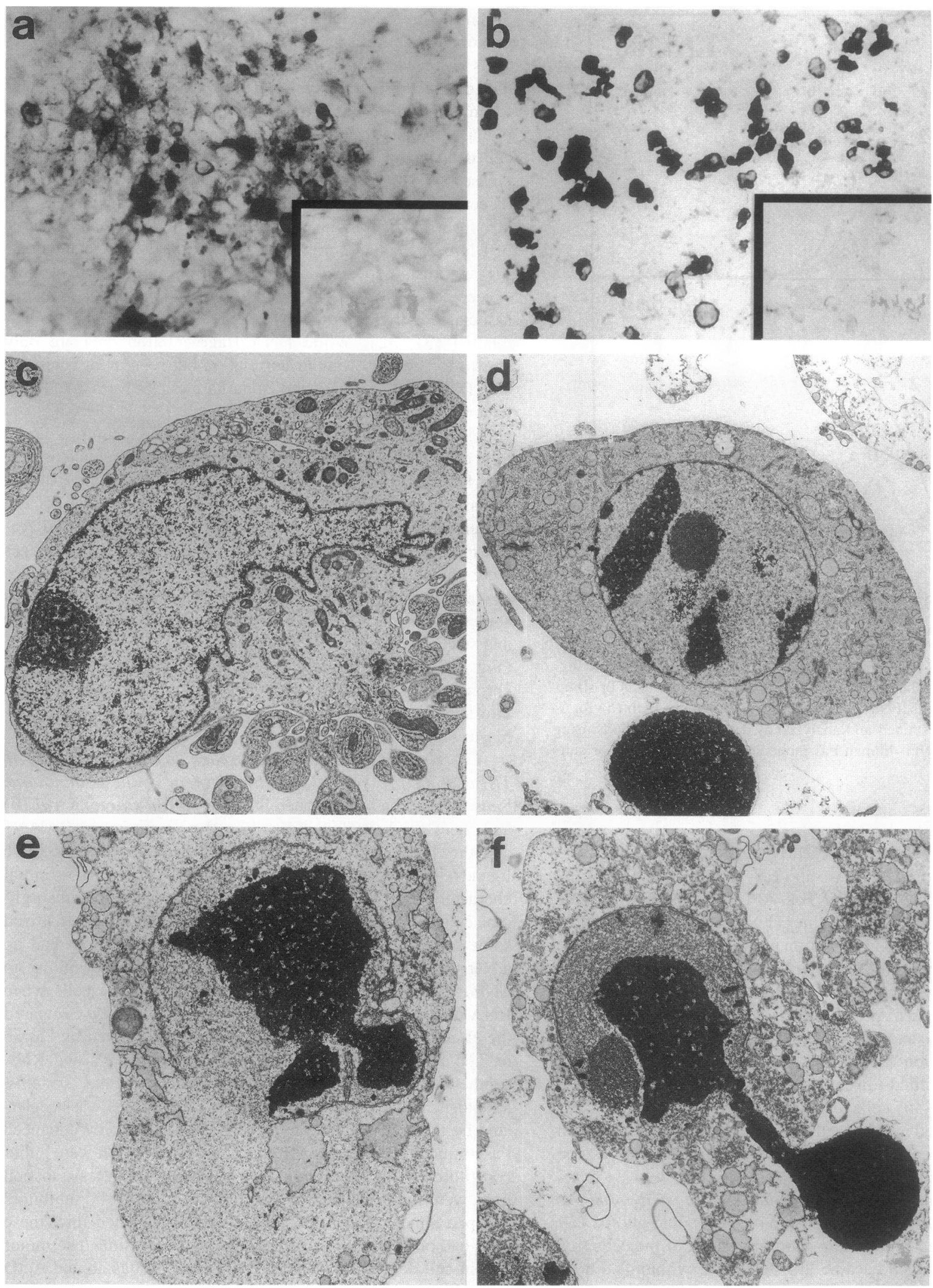

Figure 3. In situ DNA end labeling and electron microscopic analysis of LN-229 human malignant glioma cells exposed to Fas ab. ( $a$ and $b$ ) LN229 cells grown as a monolayer on glass chamber slides as described (29, see Methods) were exposed to Fas ab (10) $(1 \mu \mathrm{g} / \mathrm{ml})$ for $24 \mathrm{~h}$, fixed and processed for in situ DNA end labeling $(a)$. Detached cells were collected from the culture medium, fixed, adhered to glass slides and processed similarly $(b)$. The alkaline phosphatase substrate used produces a dark blue stain which allows the identification of DNA breaks on a single cell level. Note that a minority of adherent cells exhibit DNA breaks $(a)$ whereas virtually all detached cells are labeled $(b)(\times 268)$. The lower right inserts in $a$ and $b$ are negative controls which illustrate the absence of specific labeling when the cofactor for terminal transferase, cobalt chloride, is omitted. $(c-f)$ Morphology of Fas ab-mediated apoptosis of LN-229 cells on transmission electron microscopy. LN-229 were exposed to Fas 


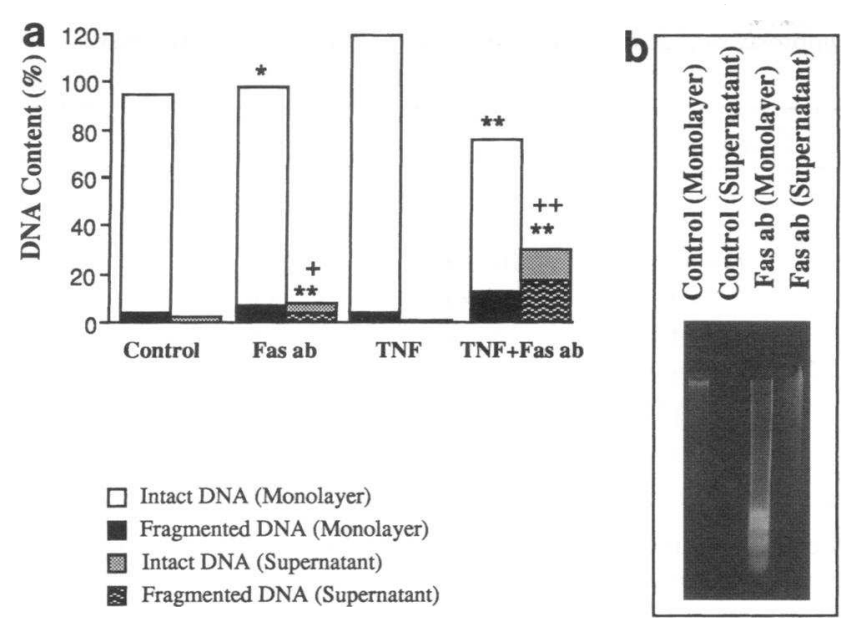

Figure 4. Fas/APO-1-mediated apoptosis of LN-229 is associated with early DNA fragmentation. (a) Soluble and pelleted DNA of adherent or detached glioma cells untreated or exposed for $18 \mathrm{~h}$ to Fas ab $(1 \mu \mathrm{g} /$ $\mathrm{ml})$, TNF $\alpha(10 \mathrm{ng} / \mathrm{ml})$ or both was subjected to Hoechst 33258 fluorometry. DNA fragmentation was increased in monolayer cells as well as in detached cells exposed to Fas ab alone or to Fas ab following TNF $\alpha$ pretreatment $(* P<0.03, * * P<0.01$ by ANOVA). Cell detachment in untreated cultures or in those exposed to TNF $\alpha$ alone was negligible and DNA barely detectable in the medium when compared to Fas ab-treated glioma cells $\left({ }^{+} P<0.03,{ }^{++} P<0.01\right.$ by ANOVA). Data are expressed as percentage relative to the total DNA in untreated control cultures including monolayer and medium and are representative of three separate experiments. SEM were below 5\%. (b) Fragmented DNA was extracted separately from monolayer and culture medium (supernatant) of $5 \times 10^{6}$ untreated LN-229 cells or of $5 \times 10^{6} \mathrm{LN}$ 229 cells exposed to Fas ab $(1 \mu \mathrm{g} / \mathrm{ml})$ for $12 \mathrm{~h}$. Only few cells have detached from the monolayer at this time point but prominent nucleosomal size fragmented DNA is recovered from the monolayer, confirming (Fig. 3, $a-b$ ) that DNA fragmentation precedes cell detachment from the monolayer in Fas ab-mediated glioma cell apoptosis.

sion electron microscopy, Hoechst 33258 fluorometry, acridine orange nuclear staining, in situ DNA end labeling and DNA agarose gel electrophoresis (data not shown). Thus, the effects of treatment with Fas ab and exposure to TNF $\alpha$ in the absence of inhibitors of RNA and protein synthesis were clearly dissociable but susceptibility to Fas/APO-1-dependent apoptosis was predictive of sensitization to TNF $\alpha$ toxicity by ActD or CHX. None of the glioma cell lines released TNF $\alpha$ constitutively as assessed by L-M fibroblast bioassay. Only LN-215 released endogenous TNF $\alpha(20 \mathrm{U} / \mathrm{ml}, 24 \mathrm{~h})$ when stimulated with LPS ( $1 \mu \mathrm{g} / \mathrm{ml}) /$ PMA (10 $\mathrm{ng} / \mathrm{ml})$.

Modulation of Fas/APO-1-mediated apoptosis of human glioma cells by cytokines. Previous work from our laboratory suggested that cytokine synthesis plays a major role in the interaction of malignant glioma cells with the immune system (2427). Given previous reports of TNF $\alpha /$ IFN $\gamma$-mediated modulation of Fas/APO-1 expression and Fas/APO-1-mediated killing $(10,19,36)$ and our own results (Fig. 1), we examined the effects of various other cytokines on Fas/APO-1 - dependent apoptosis of 5 human glioma cell lines in more detail including the four most sensitive lines, LN-18, LN-215, T98G and LN229, and one resistant line, LN-405 (Table II). Although LN18 cells were treated with a 10 times lower concentration of Fas ab $(100 \mathrm{ng} / \mathrm{ml})$ in these experiments and consequently showed less apoptosis than shown in Fig. 1, no modulation of killing by cytokines became apparent at $24 \mathrm{~h}$. In addition to IFN $\gamma$ and TNF $\alpha$, three other cytokines, TGF $\beta_{2}, \operatorname{IL} 1 \beta$, and IL8, were found to enhance Fas ab-mediated apoptosis of T98G and LN-229 cells. At concentrations reported to be effective on their respective target cells, lymphocytes and macrophages, neither IL4, IL6, IL10, IL13, nor M-CSF modulated Fas ab-mediated apoptosis of human glioma cells. Interestingly, TNF $\beta$, which shares significant sequence homology with TNF $\alpha$ and the Fas/ APO-1 ligand, similarly failed to enhance apoptosis induced by Fas/APO-1 ab. None of the cytokines when added alone had significant adverse effects on glioma cell proliferation or viability but enhanced proliferation was seen in various cell lines exposed, e.g., to TGF $\beta_{2}$, TNF $\alpha$, M-CSF, IL1, or IL6 (data not shown). More importantly, despite of the growth-promoting properties of several cytokines, none of these factors prevented or attenuated Fas ab-mediated glioma cell apoptosis.

Inhibition of Fas/APO-1-dependent glioma cell apoptosis by dexamethasone. The modulation of Fas ab-mediated apoptosis by cytokines prompted us to examine the effect of corticosteroids on glioma cell killing in our system. In the susceptible cell lines, LN-18, LN-215 and LN-229, pretreatment for $24 \mathrm{~h}$ with dexamethasone partially abrogated apoptosis induced by a subsequent Fas ab exposure. The percentage of glioma cells rescued from Fas ab-mediated apoptosis by dexamethasone $(10 \mu \mathrm{M})$ reached $* 36 \%$ in $\mathrm{LN}-18, * 26 \%$ in $\mathrm{LN}-215$, and $* 79 \%$ in LN-229 glioma cells $(n=3, * P<0.01$ by $t$ test compared with Fas ab alone; $0.1 \mu \mathrm{g} / \mathrm{ml}$ for $\mathrm{LN}-18,1 \mu \mathrm{g} / \mathrm{ml}$ for $\mathrm{LN}-215$ and $\mathrm{LN}-229$ ). Protection was less prominent when dexamethasone was added together with Fas ab, and coincubation did not augment the protection afforded by pretreatment with dexamethasone alone.

Correlation between bcl-2 expression and Fas/APO-1 sensitivity. Overexpression of antiapoptotic genes may be an important escape mechanism of tumor cells from cytotoxic stimuli. We therefore examined whether resistance to Fas/APO-1-mediated apoptosis was associated with enhanced $b c l-2$ expression (Fig. 5). LN-229 and LN-308 showed the highest levels of bcl2 protein, followed by T98G and LN-215. No signal was detected in LN-18, LN-319 and LN-405. Thus 3 of 4 sensitive but only 1 of 3 resistant glioma cell lines expressed bcl-2 protein. The data shown in Fig. 1 indicate that cell surface expression of Fas/APO-1 is the major predictor of susceptibility of the glioma cells to Fas/APO-1-mediated apoptosis. Among the sensitive cell lines which expressed high levels of Fas/APO-1, LN-18, LN-215, T98G and LN-229, higher $b c l-2$ expression was associated with lower sensitivity to Fas ab.

Expression of Fas/APO-1 on ex vivo human malignant glioma cells. Previous studies had failed to detect Fas mRNA in mouse brain (37) and APO-1 immunoreactivity in human brain

$\mathrm{ab}(1 \mu \mathrm{g} / \mathrm{ml})$ for $18 \mathrm{~h}$ and then processed for electron microscopy as described in Methods. $c(\times 7735)$ shows the appearance of a normal untreated cell, $d-f$ show different stages of apoptosis. In $d(\times 5915)$ there is typical early chromatin condensation in the nucleus but no damage to organelles. In $e(\times 6370)$ chromatin condensation is advanced and the nuclear envelope is disrupted on the upper right and lower left. In $f(\times 5550)$ nucleus and cytoplasm are packaged into apoptotic bodies and condensed heterochromatin is expelled from the cell (lower right). 
Table I. Coincubation with ActD or CHX Augments Fas ab-mediated Apoptosis and Induces Sensitivity to TNF $\alpha$-mediated Apoptosis in Fas/APO-1 ab-sensitive Human Glioma Cell Lines

\begin{tabular}{|c|c|c|c|c|c|c|c|}
\hline \multirow[b]{2}{*}{ Treatment } & \multicolumn{7}{|c|}{ Percent survival } \\
\hline & LN-18 & LN-215 & T98G & LN-229 & LN-319 & LN-405 & LN-308 \\
\hline Fas ab & $4 \pm 1^{\ddagger}$ & $72 \pm 3 *$ & $68 \pm 3^{*}$ & $116 \pm 4 *$ & $105 \pm 3$ & $103 \pm 2$ & $103 \pm 5$ \\
\hline Fas $a b+A c t D$ & $4 \pm 1^{\ddagger}$ & $0^{\ddagger}$ & $34 \pm 1^{\ddagger}$ & $7 \pm 2^{\ddagger}$ & $88 \pm 4$ & $89 \pm 2$ & $88 \pm 4$ \\
\hline Fas ab + CHX & $3 \pm 1^{\ddagger}$ & $0^{\ddagger}$ & $11 \pm 1^{\ddagger}$ & $13 \pm 3^{\ddagger}$ & $98 \pm 5$ & $92 \pm 4$ & $95 \pm 3$ \\
\hline $\mathrm{TNF} \alpha$ & $122 \pm 4 *$ & $141 \pm 4^{\ddagger}$ & $114 \pm 3$ & $155 \pm 3^{\ddagger}$ & $98 \pm 3$ & $131 \pm 3$ & $104 \pm 6$ \\
\hline $\mathrm{TNF} \alpha+\mathrm{ActD}$ & $2 \pm 1^{\ddagger}$ & $55 \pm 3^{\ddagger}$ & $27 \pm 2^{\ddagger}$ & $28 \pm 1^{\ddagger}$ & $71 \pm 2 *$ & $91 \pm 5$ & $83 \pm 4$ \\
\hline $\mathrm{TNF} \alpha+\mathrm{CHX}$ & $3 \pm 1^{\ddagger}$ & $40 \pm 3^{\ddagger}$ & $19 \pm 2^{\ddagger}$ & $37 \pm 2^{\ddagger}$ & $82 \pm 4$ & $88 \pm 2$ & $99 \pm 3$ \\
\hline
\end{tabular}

Fas ab was used at $1 \mu \mathrm{g} / \mathrm{ml}$, TNF $\alpha$ at $10 \mathrm{ng} / \mathrm{ml}$, ActD at $0.1 \mu \mathrm{g} / \mathrm{ml}$, and CHX at $1 \mu \mathrm{g} / \mathrm{ml}$ in DME/0.5\% FCS. Data are expressed as percent survival of untreated controls for cultures exposed to Fas ab or TNF $\alpha$ alone or as percent survival of cultures exposed to the respective concentrations of ActD or CHX alone. Cytotoxicity induced by ActD or CHX alone did not exceed $30 \%$. Cell loss was assessed at $24 \mathrm{~h}$ by crystal violet staining $(n$ $=3, \quad * P<0.03, \quad{ }^{\ddagger} P<0.01$ by ANOVA).

(19) but there are no data on Fas/APO-1 expression on human brain tumors. To assess whether Fas/APO-1 expression was restricted to long-term cultured human glioma cell lines or also detectable on human malignant glioma cells in vivo, we studied Fas/APO-1 expression in ex vivo human glioma specimens. Of 7 gliomas examined, three showed extensive Fas/APO-1 immunoreactivity, two showed moderate immunoreactivity, and two were negative (Fig. 6). Immunoreactivity was fairly homogenous within the single neoplasms and most pronounced at cell borders, as predicted for a membrane-associated protein. The tissue sections were taken from the center of the neoplasms to avoid confusion of tumor cells with infiltrating host cells. A glial origin of Fas/APO-1 immunoreactivity was confirmed by positive staining for glial fibrillary acidic protein in all cases.
A normal human brain autopsy specimen showed occasional Fas/APO-1 immunoreactivity on endothelial cells but brain parenchyma was negative (19). The expression of Fas/APO-1 by human malignant glioma cells in vivo was also assessed by Western blot analysis of freshly isolated human tumor cells (Fig. 7). The monoclonal IgM Fas ab recognized a band of 43 $\mathrm{kD}$ corresponding to Fas/APO-1 in 6 of 8 high-grade malignant glioma specimens.

\section{Discussion}

The failure of human malignant glioma to respond to current treatment protocols requires the evaluation of novel treatment strategies. This study shows that malignant glioma cells express

Table II. Modulation of Fas/APO-1-mediated Apoptosis by Preexposure to Cytokines

\begin{tabular}{|c|c|c|c|c|c|c|c|c|c|c|}
\hline \multirow{3}{*}{$\begin{array}{l}\text { Pretreatment } \\
\text { None }\end{array}$} & \multicolumn{10}{|c|}{ Percent survival and toxicity by light microscopy } \\
\hline & \multicolumn{2}{|c|}{ LN-18 } & \multicolumn{2}{|c|}{ LN-215 } & \multicolumn{2}{|c|}{ T98G } & \multicolumn{2}{|c|}{ LN-229 } & \multicolumn{2}{|c|}{ LN-405 } \\
\hline & $31 \pm 3$ & ++ & $52 \pm 4$ & + & $51 \pm 3$ & + & $96 \pm 3$ & + & $98 \pm 4$ & - \\
\hline $\mathrm{TNF} \alpha(10 \mathrm{ng} / \mathrm{ml})$ & $28 \pm 2$ & ++ & $31 \pm 3^{\ddagger}$ & ++ & $21 \pm 1^{\ddagger}$ & ++ & $31 \pm 1^{\ddagger}$ & ++ & $85 \pm 3$ & - \\
\hline $\mathrm{IFN} \gamma(100 \mathrm{U} / \mathrm{ml})$ & $31 \pm 2$ & ++ & $35 \pm 3 *$ & ++ & $41 \pm 2^{*}$ & + & $92 \pm 5$ & + & $93 \pm 7$ & - \\
\hline $\mathrm{TGF} \beta_{2}(10 \mathrm{ng} / \mathrm{ml})$ & $34 \pm 3$ & ++ & $37 \pm 4 *$ & ++ & $38 \pm 3 *$ & + & $62 \pm 4 *$ & ++ & $93 \pm 8$ & - \\
\hline $\mathrm{TNF} \alpha / \mathrm{IFN} \gamma$ & $25 \pm 2$ & ++ & $32 \pm 2^{\ddagger}$ & ++ & $20 \pm 1^{\ddagger}$ & ++ & $28 \pm 2^{\ddagger}$ & ++ & $102 \pm 4$ & - \\
\hline $\mathrm{TNF} \alpha / \mathrm{TGF} \beta_{2}$ & $30 \pm 3$ & ++ & $31 \pm 3^{\ddagger}$ & ++ & $24 \pm 2^{\ddagger}$ & ++ & $40 \pm 3^{\ddagger}$ & ++ & $108 \pm 3$ & - \\
\hline IFN $\gamma / \mathrm{TGF} \beta_{2}$ & $35 \pm 2$ & ++ & $39 \pm 2 *$ & + & $43 \pm 3$ & + & $71 \pm 6^{*}$ & + & $98 \pm 5$ & - \\
\hline $\mathrm{TNF} \beta(20 \mathrm{ng} / \mathrm{ml})$ & $34 \pm 3$ & ++ & $45 \pm 3$ & + & $46 \pm 4$ & + & $91 \pm 5$ & + & $100 \pm 3$ & - \\
\hline $\operatorname{ILl} \beta(2.50 \mathrm{ng} / \mathrm{ml})$ & $39 \pm 4$ & ++ & $40 \pm 2 *$ & + & $40 \pm 3 *$ & + & $62 \pm 4 *$ & ++ & $85 \pm 2$ & - \\
\hline IL4 $(5 \mathrm{ng} / \mathrm{ml})$ & $34 \pm 3$ & ++ & $53 \pm 2$ & + & $42 \pm 3$ & + & $83 \pm 2$ & + & $97 \pm 3$ & - \\
\hline IL6 (100 U/ml) & $34 \pm 3$ & ++ & $44 \pm 3$ & + & $42 \pm 3$ & + & $87 \pm 7$ & + & $93 \pm 4$ & - \\
\hline IL8 $(20 \mathrm{ng} / \mathrm{ml})$ & $31 \pm 2$ & ++ & $51 \pm 4$ & + & $28 \pm 2 *$ & ++ & $75 \pm 3 *$ & ++ & $86 \pm 5$ & - \\
\hline IL10 (10 ng/ml) & $31 \pm 1$ & ++ & $50 \pm 3$ & + & $37 \pm 2 *$ & + & $78 \pm 5$ & + & $81 \pm 2$ & - \\
\hline IL13 (10 ng/ml) & $35 \pm 4$ & ++ & $56 \pm 3$ & + & $41 \pm 3 *$ & + & $88 \pm 4$ & + & $93 \pm 4$ & - \\
\hline M-CSF $(10 \mathrm{U} / \mathrm{ml})$ & $33 \pm 3$ & ++ & $49 \pm 1$ & + & $43 \pm 3$ & + & $96 \pm 6$ & + & $101 \pm 5$ & - \\
\hline
\end{tabular}

The cytokines were added to the cultures for $24 \mathrm{~h}$ in DME/10\% FCS at the concentrations indicated. The cells were washed and then exposed to Fas ab $(1 \mu \mathrm{g} / \mathrm{ml} ; 0.1 \mu \mathrm{g} / \mathrm{ml}$ for $\mathrm{LN}-18)$ in DME/0.5\% FCS for $24 \mathrm{~h}$. Viability was assessed by crystal violet staining. Cytotoxicity was rated -, ,+++ as described in Methods. Note that, while there is generally good correlation between cytotoxicity data from crystal violet staining and visual ratings, there are instances of definite toxicity associated with no significant changes of total viable cell yields, e.g., in LN-229 cells, a finding explained by dual cytokine action including stimulation of growth and sensitization to Fas ab. Data are expressed as percent survival of untreated controls (mean and SEM, ${ }^{*} P<0.05,{ }^{\ddagger} P<0.01$ by ANOVA compared to cell cultures exposed to Fas ab alone) and are representative of experiments repeated three times with similar results. 
Fas/APO-1 and undergo apoptosis when exposed to Fas ab. Thus, the endogenous death pathway of apoptosis can be activated in human malignant glioma cells. The expression of Fas/ APO-1 on malignant glioma cells was enhanced by TNF $\alpha$ and IFN $\gamma$. Fas ab-mediated cytotoxicity was significantly augmented by exogenous cytokines including not only TNF $\alpha$ and IFN $\gamma$ but also TGF $\beta_{2}, \operatorname{IL} 1 \beta$, and IL8. These findings hold promise for therapeutic approaches to malignant glioma targeting Fas/APO-1 since endogenous enhancers of sensitivity to Fas/APO- 1 ab like TGF $\beta_{2}$ or IL 8 are released by malignant glioma cells in vivo $(25,27,38-45)$. The modulation of susceptibility to Fas/APO-1 ligation by these cytokines including their uniform failure to block Fas/APO-1-dependent apoptosis is interesting both for the understanding of Fas/APO-1-mediated apoptosis of malignant glioma cells and for the design of future immunotherapy strategies. In this regard inhibition of Fas/APO-1-dependent glioma cell apoptosis by dexamethasone is also noteworthy since malignant glioma patients usually receive high doses of steroids.

Expression of Fas/APO-1 in tumor cells other than malignant glioma is heterogeneous: while bronchogenic carcinoma, rhabdomyosarcoma, melanoma and small cell lung carcinoma are Fas/APO-1-negative or only weakly positive, ductal invasive mammary carcinoma as well as renal cell carcinoma, leiomyosarcoma and B cell neoplasms are usually positive (19). Colorectal carcinomas can be either positive, weakly positive or negative. Selected Fas/APO-1-susceptible human tumor cell lines other than lymphoid cells included rhabdomyosarcoma, colon and ovarian carcinoma, melanoma and transformed fibroblasts $(10,36,46)$. Induction of Fas/APO-1 cell surface expression by IFN $\gamma$ and TNF $\alpha$ has been described (10, 19, 37, 47). Our data suggest that cytokine-mediated upregulation of Fas/APO-1 expression may not be the only mechanism of cytokine-mediated sensitization of human glioma cells to Fas abmediated cytotoxicity since IFN $\gamma$ enhanced Fas/APO-1 expression of LN-319 or T98G cells in the absence of augmentation of killing and since TNF $\alpha$ induced killing of LN-319 cells in the absence of enhanced Fas/APO-1 expression (Fig. 1). A combination of cytokines may be most efficient in enhancing both Fas/APO-1 expression and susceptibility to Fas ab-mediated killing. Resistance to Fas/APO-1 ab despite cell surface expression of the antigen as seen in IFN $\gamma / \mathrm{TNF} \alpha$-treated LN405 cells (Fig. 1) is not a unique feature of malignant glioma cells but has been described in resting and activated human

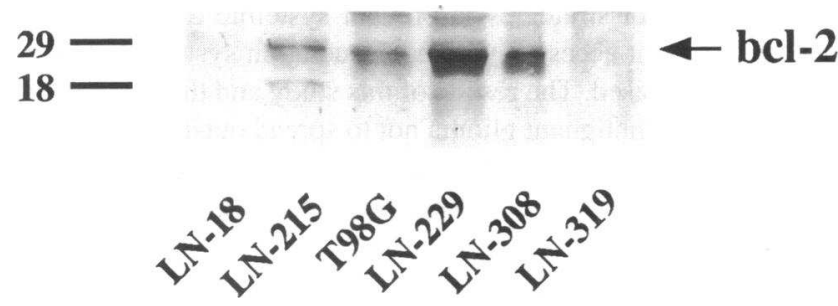

Figure 5. Bcl-2 protein expression of Fas/APO-1-sensitive and resistant human glioma cell lines. 12.5\% SDS PAGE and Western blot analysis performed as described in Methods allowed the detection by anti-human bcl-2 ab of a $26-\mathrm{kD}$ protein in gliomas $\mathrm{LN}-215$, T98G, $\mathrm{LN}-229$, and $\mathrm{LN}-405$. This band was not detected when the monoclonal bcl-2 ab was substituted by non-immune mouse IgG. U937 monocytic leukemia served as a positive control (data not shown). $20 \mu \mathrm{g}$ protein were loaded per lane. Size markers of 18 and $29 \mathrm{kD}$ are indicated on the left.

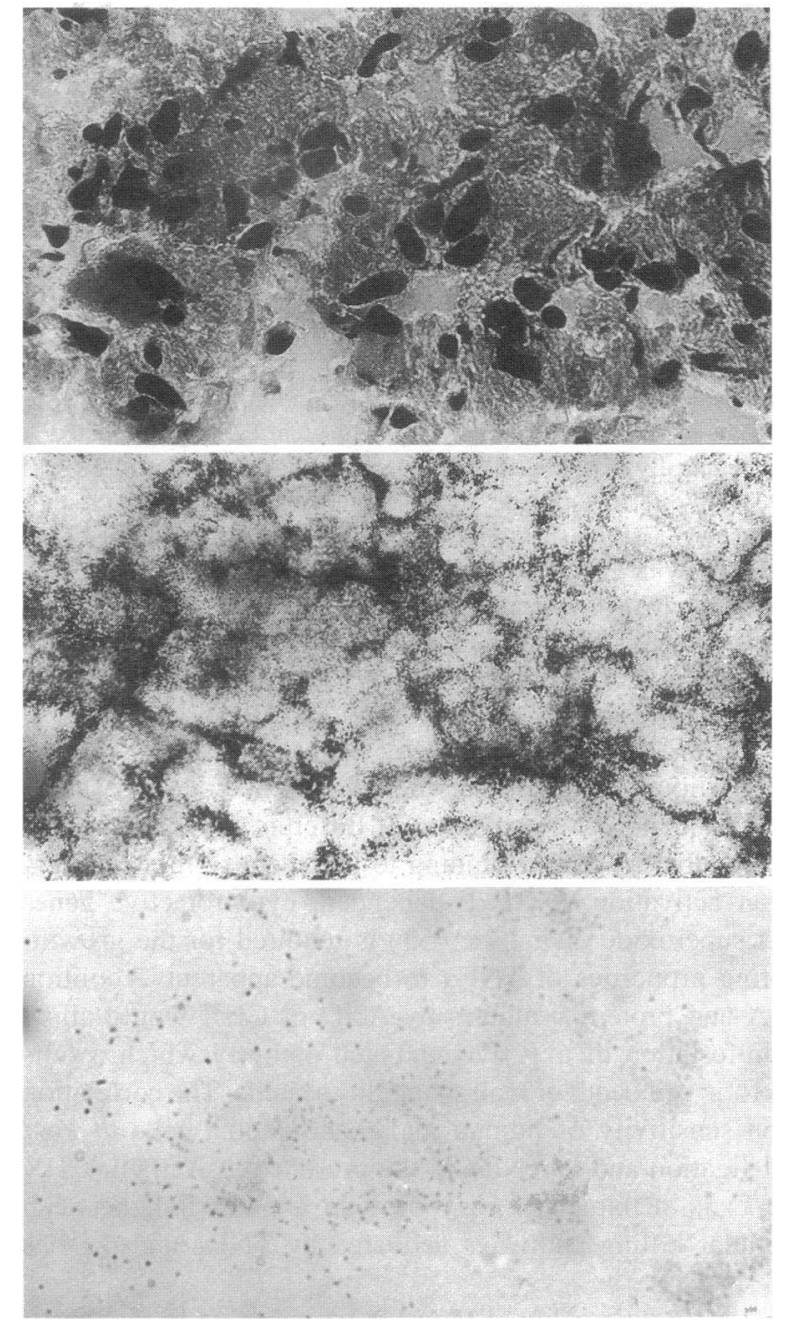

Figure 6. Immunocytochemical detection of Fas/APO-1 expression in human malignant glioma tissue. The upper panel shows a hematoxylin eosin routine stain of a human malignant glioma cryosection. Numerous dark nuclei are readily recognized in this cell-rich area of the tumor. The middle panel shows Fas/APO-1 immunoreactivity detected as described in Methods in a similar region of the same tumor. Note the prominent labeling of cell borders which localizes most Fas/APO-1 immunoreactivity to the cell membranes. There is also cytoplasmic staining in a significant proportion of glioma cells. Nuclei are negative. The lower panel is a negative control which shows absence of specific immunoreactivity when Fas/APO-1 ab is replaced with non-immune mouse IgG $(\times 295)$.

peripheral blood lymphocytes $(48,49)$ as well as in lymphoid and nonlymphoid malignant cell lines $(46,50,51)$. Although the observation of enhanced proliferation following Fas ab exposure in some cell lines appears to confirm that Fas/APO-1 may not exclusively signal cell death $(46,51,52)$, we have not formally excluded the possibility that, within a given glioma cell line, enhanced proliferation after Fas ab exposure is an indirect effect of Fas-mediated killing of some glioma cells, resulting either in reactive mitogenicity or clonal expansion of resistant cells. Taken together, these observations highlight the significance of the intracellular cascade triggered by Fas/APO1 ligation and of its possible regulation by cytokines.

TNF $\alpha$-mediated glioma cell proliferation in the absence of inhibitors of RNA and protein synthesis contrasted with TNF $\alpha$ - 


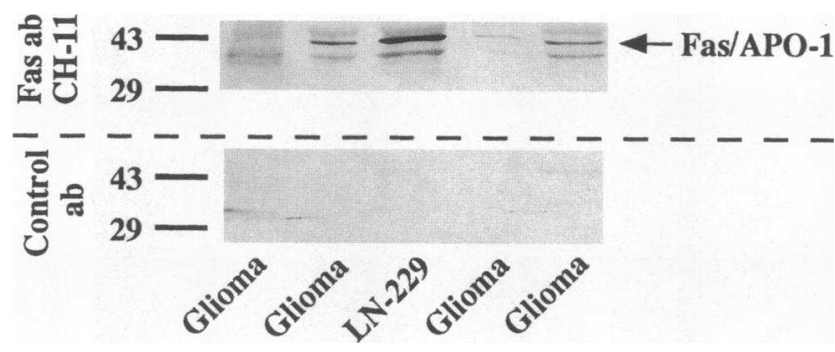

Figure 7. Detection of Fas/APO-1 expression in human malignant gliomas ex vivo by Western blotting. Soluble protein $(20 \mu \mathrm{g})$ extracted from mechanically dissociated fresh human malignant glioma cells was analysed by Western blotting as described in Methods. After electrophoretic separation and transfer to nitrocellulose, the protein samples were reacted either with Fas IgM ab ( $5 \mu \mathrm{g} / \mathrm{ml}$ ) (upper panel) or with nonimmune mouse IgM (lower panel). LN-229 glioma cells (lane 3 ) served as a positive control. Fas/APO-1 was detected in three (lanes 2, 4, and 5) of four gliomas in this experiment.

mediated glioma cell apoptosis in the presence of such agents (Table I) and suggests activation of different intracellular cascades triggered by TNF $\alpha$ binding to its receptor. It is conceivable that activation of NF $\kappa \mathrm{B}$-dependent cytoprotective genes such as superoxide dismutase (53) is required for the growthpromoting properties of TNF $\alpha$ to become apparent. Abolition of RNA and protein synthesis by ActD or CHX would allow the manifestation of a TNF $\alpha$-mediated pathway which results in apoptotic cell death of malignant glioma cells. The correlation between sensitivity of human malignant glioma cells to Fas/ APO-1 ligation and to TNF $\alpha$ in the presence of ActD or CHX (Table I) is striking and may provide another link between intracellular killing pathways activated by TNF $\alpha$ and the Fas ligand.

The therapeutic value of Fas/APO-1 targeting in malignant glioma might be limited by a significant proportion of glioma cells which do not express Fas/APO-1 or which despite cell surface expression of Fas/APO-1 exhibit resistance to Fas/ APO-1 ab-mediated apoptosis. The identification of stimuli other than those examined herein to induce Fas/APO-1 expression is therefore an important task. Efforts to identify mechanisms underlying resistance to Fas ab-mediated apoptosis despite expression of Fas/APO-1 showed that this phenomenon is probably not linked to overexpression of the antiapoptotic proto-oncogene, $b c l-2$ (Fig. 5). Abrogation of Fas ab-mediated apoptosis by enforced $b c l-2$ expression has been reported in murine IL3-dependent FDC-P1 cells and WR19L lymphoma cells (54). A possible association of decreased $b c l-2$ mRNA with enhanced susceptibility to APO-1 ab was detected in human B cell leukemias (51). Anti-oxidant properties of $b c l-2$ (55) and the putative role of oxygen free radicals in TNF $\alpha$ mediated killing $(34,35,53)$ further suggested that $b c l-2$ overexpression might induce resistance to Fas/APO-1-mediated apoptosis in specific cell types.

The apparent lack of correlation between Fas/APO-1 ab sensitivity and $b c l-2$ expression in human malignant glioma cell lines (Fig. 5) is consistent with the failure of $b c l-2$ to prevent TNF $\alpha$ cytotoxicity (56) and killing by cytotoxic T cells (57) which may involve Fas/APO-1 expression on target cells (18). Further studies are needed to clarify a possible role of $b c l-2$ expression in the resistance of malignant glioma cells to Fas/ APO-1-dependent apoptosis. Bcl-2 expression in malignant glioma in vivo may be indicative of malignant transformation, possibly contributing to radioresistance, since normal astrocytes do not express $b c l-2$ in vivo (58).

Immunotherapy of human malignant glioma targeting Fas/ APO-1 in vivo requires the presence or inducibility of Fas/ APO-1 not only in malignant glioma cell lines but also in malignant gliomas in vivo and the absence of Fas/APO-1 on nontransformed neurons and astrocytes or the failure of these cells to activate the endogenous death program of apoptosis in response to agonistic Fas/APO-1 ab. Cloning of Fas/APO-1 $(12,13)$ and its ligand $(21,22)$ has allowed to study their expression in vivo. Fas/APO-1 mRNA was detected in mouse thymus, liver, ovary and heart but not in brain (37). These data correspond to the absence of Fas/APO-1 protein in brain in immunohistological studies of normal adult human tissue. Neither neurons nor astrocytes, oligodendrocytes, microglial or ependymal cells displayed immunoreactive Fas/APO-1 protein although $\sim 50 \%$ of central nervous system endothelial cells were positive (19). Fas/APO-1 protein was detected in numerous other cell types including hepatocytes, subpopulations of keratinocytes, lymphocytes, or intestinal tract epithelial cells. Fas ligand mRNA is expressed in rat splenocytes, testis, lung, kidney, and small intestine but again not in brain (21). The absence of Fas/APO-1 in normal brain parenchyma is the first prerequisite of Fas/APO-1 targeting immunotherapy for malignant glioma, this is prevention of widespread tissue damage in normal brain. While this precondition appears to be met (19), it remains to be investigated whether reactive astrocytes around the tumor tissue are Fas/APO-1-positive or would become so upon pre- or co-treatment with exogenous cytokines. The expression of Fas/APO-1 not only on cultured glioma cells but also on ex vivo human glioma specimens is the second precondition for Fas/APO-1 targeting to become a therapeutic approach to malignant glioma. Our data (Fig. 6) show that expression of Fas/APO-1 expression is not a consequence of long-term glioma cell culturing but is also detectable in vivo. Further experimentation is required to assess Fas/APO-1 expression in an extended sample of brain tumor specimens and to evaluate susceptibility to Fas ab-mediated cytotoxicity of fresh human glioma tissue. Locoregionary approaches via Ommaya reservoir and cerebrospinal fluid or via carotid and vertebral arteries have previously been employed to deliver lymphokine-activated killer cells or systemically toxic agents like immunoconjugates or TNF $\alpha$ to brain tumors $(1,59,60)$. Since systemic application of Fas ab in mice resulted in death from acute liver failure (61), Fas/APO-1 -targeting immunotherapy of malignant glioma will similarly have to be studied as a locoregionary approach unless pharmacological strategies to prevent systemic toxicity and to assure sufficient access to glioma tissue upon systemic application can be devised. The results of this study and the characteristics feature of malignant glioma not to spread outside the central nervous system suggest that these neoplasms are a putative target for Fas/APO-1-targeting oncological immunotherapy.

\section{Acknowledgments}

The authors thank Dr. N. de Tribolet (Lausanne, Switzerland) for providing most of the human glioma cell lines used in this study, Dr. B. Schäubler (Zürich, Switzerland) for providing human glioma cryosections, Dr. D. Mason (Oxford, UK) for a generous supply of anti-human bcl-2 ab, and Ms. E. Niederer for excellent technical assistance in flow cytometry analysis.

This study was supported by grants from the Swiss National Science Foundation to A. Fontana (31-28402.90), the National Multiple Sclero- 
sis Society and the Tumor Centre Heidelberg/Mannheim. M. Weller is a postdoctoral fellow of the German Research Foundation.

\section{References}

1. Deen, F. D., A. Chiarado, E. A. Grimm, J. R. Fike, M. A. Israel, L. E Kun, V. A. Levin, L. J. Marton, R. J. Packer, A. E. Pegg, M. L. Rosenblum, H. D. Suit, M. D. Walker, C. J. Wikstrand, C. B. Wilson, A. J. Wong, and W. K. A. Yung. 1993. Brain tumor working group report on the 9th International Conference on Brain Tumor Research and Therapy. J. Neuro-Oncol. 16:243272.

2. Korsmeyer, S. J. 1992. Bcl-2: an antidote to programmed cell death. Cancer Surv. 15:105-118.

3. Kerr, J. F. R., A. H. Wyllie, and A. R. Currie. 1972. Apoptosis: a basic biological phenomenon with wide-ranging implications in tissue kinetics. $B r$. $J$. Cancer. 26:239-257.

4. Cohen, J. J. 1993. Apoptosis. Immunol. Today. 14:126-130.

5. Schwartz, L. M., and B. A. Osborne. 1993. Programmed cell death apoptosis and killer genes. Immunol. Today. 14:582-590.

6. Schwartzman, R. A., and J. A. Cidlowski. 1993. Apoptosis: the biochemistry and molecular biology of programmed cell death. Endocr. Rev. 14:133-151.

7. Barry, M. A., C. A. Behnke, and A. Eastman. 1990. Activation of programmed cell death (apoptosis) by cisplatin, other anticancer drugs, toxins and hyperthermia. Biochem. Pharmacol. 40:2353-2362.

8. Sen, S., and M. D'Incalci. 1992. Apoptosis. Biochemical events and relevance to cancer chemotherapy. FEBS (Fed. Eur. Biochem. Soc.) Lett. 307:122127.

9. Reed, J. C. 1994. Bcl-2 and the regulation of programmed cell death. J. Cell Biol. 124:1-6.

10. Yonehara, S., A. Ishii, and M. Yonehara. 1989. A cell-killing monoclonal antibody (anti-Fas) to a cell surface antigen co-downregulated with the receptor of tumor necrosis factor. J. Exp. Med. 169:1747-1756.

11. Trauth, B. C., C. Klas, A. M. J. Peters, S. Matzku, P. Möller, W. Falk, K. M. Debatin, and P. H. Krammer. 1989. Monoclonal antibody-mediated tumor regression by induction of apoptosis. Science (Wash. DC). 245:301-305.

12. Itoh, N., S. Yonehara, A. Ishii, M. Yonehara, S. I. Mizushima, M. Sameshima, A. Hase, Y. Seto, and S. Nagata. 1991. The polypeptide encoded by the cDNA for human cell surface antigen Fas can mediate apoptosis. Cell. 66:233243.

13. Oehm, A., I. Behrmann, W. Falk, M. Pawlita, G. Maier, C. Klas, M. LiWever, S. Richards, J. Dhein, B. C. Trauth, H. Ponstingl, and P. H. Krammer 1992. Purification and molecular cloning of the APO-1 cell surface antigen, member of the tumor necrosis factor/nerve growth factor receptor superfamily. Sequence identity with the Fas antigen. J. Biol. Chem. 267:10709-10715.

14. Itoh, N., and S. Nagata. 1993. A novel protein domain required for apoptosis. Mutational analysis of human fas antigen. J. Biol. Chem. 268:1093210937.

15. Tartaglia, L. A., T. M. Ayres, G. H. W. Wong, and D. V. Goeddel. 1993. A novel domain within the $55 \mathrm{kd}$ TNF receptor signals cell death. Cell. 74:845853.

16. Watanabe-Fukunaga, R., C. I. Brannan, N. G. Copeland, N. A. Jenkins, and S. Nagata. 1992. Lymphoproliferation disorder in mice explained by defects in Fas antigen that mediates apoptosis. Nature (Lond.). 356:314-317.

17. Debatin, K. M., D. Süss, and P. H. Krammer. 1994. Differential expression of APO-1 on human thymocytes: implications for negative selection. Eur. $J$. Immunol. 24:753-758.

18. Rouvier, E., M. L. Luciani, and P. Golstein. 1993. Fas involvement in Ca2+-independent T cell-mediated cytotoxicity. J. Exp. Med. 177:195-200.

19. Leithäuser, F., J. Dhein, G. Mechtersheimer, K. Koretz, S. Brüderlein, C. Henne, A. Schmidt, K. M. Debatin, P. H. Krammer, and P. Möller. 1993. Constitutive and induced expression of APO-1, a new member of the nerve growth factor/ tumor necrosis factor receptor superfamily, in normal and neoplastic cells. Lab. Invest. 69:415-429.

20. Dhein, J., P. T. Daniel, B. C. Trauth, A. Oehm, P. Möller, and P. H. Krammer. 1992. Induction of apoptosis by monoclonal antibody anti-APO-1 class switch variants is dependent on cross-linking of APO-1 cell surface antigens. $J$. Immunol. 149:3166-3173.

21. Suda, T., T. Takahashi, P. Golstein, and S. Nagata. 1993. Molecular cloning and expression of the Fas ligand, a novel member of the tumor necrosis factor family. Cell. 75:1169-1178.

22. Suda, T., and S. Nagata. 1994. Purification and characterization of the Fas-ligand that induces apoptosis. J. Exp. Med. 179:873-879.

23. Fontana, A., W. Fierz, and H. Wekerle. 1984. Astrocytes present myelin basic protein to encephalitogenic T-cell lines. Nature (Lond.). 307:273-276.

24. Fontana, A., H. Hengartner, N. de Tribolet, and E. Weber. 1984. Glioblastoma cells release interleukin 1 and factors inhibiting interleukin 2-mediated effects. J. Immunol. 132:1837-1844.

25. Bodmer, S., K. Strommer, K. Frei, C. Siepl, N. de Tribolet, I. Heid, and A. Fontana. 1989. Immunosuppression and transforming growth factor- $\beta$ in glioblastoma. Preferential production of transforming growth factor- $\beta 2$. J. Immunol. 143:3222-3229.

26. Constam, D. B., J. Philipp, U. V. Malipiero, P. Ten Dijke, M. Schachner, and A. Fontana. 1992. Differential expression of transforming growth factor- $\beta 1$, $\beta 2$, and $\beta 3$ by glioblastoma cells, astrocytes, and microglia. J. Immunol. 148:1404-1410.

27. Frei, K., D. Piani, U. V. Malipiero, E. Van Meir, N. de Tribolet, and A. Fontana. 1992. Granulocyte-macrophage colony-stimulating factor (GM-CSF) production by glioblastoma cells. Despite the presence of inducing signals GMCSF is not expressed in vivo. J. Immunol. 148:3140-3146.

28. Frei, K., C. Siepl, P. Groscurth, S. Bodmer, C. Schwerdel, and A. Fontana 1987. Antigen presentation and tumor cytotoxicity by interferon- $\gamma$-treated microglial cells. Eur. J. Immunol. 17:1271-1278.

29. Weller, M., D. B. Constam, U. Malipiero, and A. Fontana. 1994. Transforming growth factor- $\beta_{2}$ induces apoptosis of murine $\mathrm{T}$ cell clones without downregulating $b c l-2$ mRNA expression. Eur. J. Immunol. 24:1293-1300.

30. Gavrieli, Y., Y. Sherman, and S. A. Ben-Sasson. 1992. Identification of programmed cell death in situ via specific labeling of nuclear fragmentation. $J$. Cell Biol. 119:493-501.

31. Shi, Y., M. G. Szalay, L. Paskar, M. Boyer, B. Singh, and D. R. Green 1990. Activation-induced cell death in T cell hybridomas is due to apoptosis. Morphologic aspects and DNA fragmentation. J. Immunol. 144:3326-3333.

32. Arends, M. J., R. G. Morris, and A. H. Wyllie. 1990. Apoptosis. The role of the endonuclease. Am. J. Pathol. 136:593-608.

33. Zuber, P., R. S. Accolla, S. Carrel, A. C. Diserens, and N. de Tribolet 1988. Effects of recombinant human tumor necrosis factor- $\alpha$ on the surface phenotype and the growth of human malignant glioma cell lines. Int. J. Cancer. 42:780786.

34. Larrick, J. W., and S. C. Wright. 1990. Cytotoxic mechanism of tumor necrosis factor- $\alpha$. FASEB (Fed. Am. Soc. Exp. Biol.) J. 4:3215-3223.

35. Vassalli, P. 1992. The pathophysiology of tumor necrosis factors. Annu. Rev. Immunol. 10:411-452.

36. Morimoto, H., S. Yonehara, and B. Bonavida. 1993. Overcoming tumor necrosis factor and drug resistance of human tumor cell lines by combination treatment with anti-fas antibody and drugs or toxins. Cancer Res. 53:2591-2596.

37. Watanabe-Fukunaga, R, C. I Brennan, N. Itoh, S. Yonehara, N. G. Copeland, N. A. Jenkins, and S. Nagata. 1992. The cDNA structure, expression, and chromosomal assignment of the mouse Fas antigen. J. Immunol. 148:12741279.

38. Maxwell, M., T. Galanopoulos, J. Neville-Golden, and H. N. Antoniades 1992. Effect of the expression of transforming growth factor- $\beta 2$ in primary human glioblastomas on immunosuppression and loss of immune surveillance. J. Neurosurg. 76:799-784.

39. Black, K. L., K. Chen, D. P. Becker, and J. E. Merril. 1992. Inflammatory leukocytes associated with increased immunosuppression by glioblastoma. J. Neurosurg. 77:120-126.

40. Horst, H. A., B. W. Scheithauer, P. J. Kelly, and J. S. Kovach. 1992. Distribution of transforming growth factor- $\beta_{1}$ in human astrocytomas. Hum. $\mathrm{Pa}$ thol. 23:1284-1288.

41. Schneider, J., F. M. Hofman, M. L. J. Apuzzo, and D. R. Hinton. 1992. Cytokines and immunoregulatory molecules in malignant glial neoplasms. $J$. Neurosurg. 77:265-273.

42. Tada, M., Y. Sawamura, S. Sakuma, K. Suzuki, H. Ohta, T. Aida, and H Abe. 1993. Cellular and cytokine responses of the human central nervous system to intracranial administration of tumor necrosis factor $\alpha$ for the treatment of malignant gliomas. Cancer Immunol. Immunother. 36:251-259.

43. Tada, T., K. Yabu, and S. Kobayashi. 1993. Detection of active form of transforming growth factor $\beta$ in cerebrospinal fluid of patients with glioma. JPN. J. Cancer Res. 84:544-548.

44. Ruffini, P. A., L. Rivoltini, A. Silvani, A. Boiardi, and G. Parmiani. 1993. Factors, including transforming growth factor $\beta$, released in the glioblastoma residual cavity, impair activity of adherent lymphokine-activated killer cells. Cancer Immunol. Immunother. 36:409-416.

45. Van Meir, E., M. Ceska, F. Effenberger, A. Walz, E. Grouzman, I. Desbaillets, K. Frei, A. Fontana, and N. de Tribolet. 1992. Interleukin-8 is produced in neoplastic and infectious diseases of the human central nervous system. Cancer Res. 52:4297-4305.

46. Owen-Schaub, L. B., S. Meterissian, and R. J. Ford. 1993. Fas/APO-1 expression and function on malignant cells of hematologic and nonhematologic origin. J. Immunotherapy. 14:234-241.

47. Möller, P., C. Henne, F. Leithäuser, A. Eichelmann, A. Schmidt, S. Brüderlein, J. Dhein, and P. H. Krammer. 1993. Coregulation of the APO-1 antigen with intercellular adhesion molecule-1 (CD54) in tonsillar B cells and coordinate expression in follicular center B cells and in follicle center and mediastinal Bcell lymphomas. Blood. 81:2067-2075.

48. Miyawaki, T., T. Uehara, R. Nibu, T. Tsuji, A. Yachie, S. Yonehara, and N. Taniguchi. 1992. Differential expression of apoptosis-related fas antigen on lymphocyte subpopulations in human peripheral blood. J. Immunol. 149:37533758 .

49. Klas, C., K. M. Debatin, R. R. Jonker, and P. H. Krammer. 1993. Activa- 
tion interferes with the APO-1 pathway in mature human T cells. Int. Immunol. 5:625-630.

50. Falk, M. H., B. C. Trauth, K. M. Debatin, C. Klas, C. D. Gregory, A. B. Rickinson, A. Calender, G. M. Lenoir, J. W. Ellwart, P. H. Krammer, and G. W. Bornkamm. 1992. Expression of the APO-1 antigen in Burkitt lymphoma cel lines correlates with a shift towards a lymphoblastoid phenotype. Blood. 79:33003306.

51. Mapara, M. Y., R. Bargou, C. Zugck, H. Döhner, F. Ustaoglu, R. R. Jonker, P. H. Krammer, and B. Dörken. 1993. APO-1 mediated apoptosis or proliferation in human chronic B lymphocytic leukemia: correlation with bcl-2 oncogene expression. Eur. J. Immunol. 23:702-708.

52. Alderson, M. R., R. J. Armitage, E. Maraskovsky, T. W. Tough, E. Roux, K. Schooley, F. Ramsdell, and D. H. Lynch. 1993. Fas transduces activation signals in normal human T lymphocytes. J. Exp. Med. 178:2231-2235.

53. Wong, G. H. W., J. H. Elwell, L. W. Oberley, and D. V. Goeddel. 1989. Manganous superoxide dismutase is essential for cellular resistance to cytotoxicity of tumor necrosis factor. Cell. 58:923-931.

54. Itoh, N., Y. Tsujimoto, and S. Nagata. 1993. Effect of bcl-2 on Fas antigenmediated cell death. J. Immunol. 151:621-627.

55. Hockenbery, D. M., Z. N. Oltvai, X. M. Yin, C. L. Milliman, and S. J.
Korsmeyer. 1993. Bcl-2 functions in an antioxidant pathway to prevent apoptosis. Cell. 75:241-251.

56. Vanhaesebroeck, B., J. C. Reed, D. De Valck, J. Grooten, T. Miyashita, S. Tanaka, R. Beyaert, F. Van Roy, and W. Fiers. 1993. Effect of $b c l-2$ protooncogene expression on cellular sensitivity to tumor necrosis factor-mediated cytotoxicity. Oncogene. 8:1075-1081.

57. Vaux, D. L., H. L. Aguila, and I. L. Weissman. 1992. Bcl-2 prevents death of factor-deprived cells but fails to prevent apoptosis in targets of cell mediated killing. Int. Immunol. 4:821-824.

58. Hockenbery, D. M., M. Zutter, W. Hickey, M. Nahm, and S. J. Korsmeyer. 1991. BCL2 protein is topographically restricted in tissues characterized by apoptotic cell death. Proc. Natl. Acad. Sci. USA. 88:6961-6965.

59. Hall, W. A., and O. Fodstad. 1992. Immunotoxins and central nervous system neoplasia. J. Neurosurg. 76:1-12.

60. Yoshida, J., T. Wakabayashi, M. Mizuno, K. Sugita, T. Yoshida, S. Hori, T. Mori, T. Sato, A. Karashima, K. Kurisu, K. Kiya, and T. Uozumi. 1992. Clinical effect of intra-arterial tumor necrosis factor- $\alpha$ for malignant glioma. $J$. Neurosurg. 77:78-83.

61. Ogasawara, J., R. Watanabe-Fukunaga, M. Adachi, A. Matsuzawa, T. Kasugai, Y. Kitamura, N. Itoh, T. Suda, and S. Nagata. 1993. Lethal effect of the anti-Fas antibody in mice. Nature (Lond.). 364:806-809. 